\title{
Production of Rhodotorula glutinis: a yeast that secretes $\alpha-L-$ arabinofuranosidase
}

\author{
Claudio Martínez \\ Departamento de Ciencia y Tecnología de los Alimentos \\ Facultad Tecnológica and Centro de Estudios en Ciencia y Tecnología de los Alimentos \\ Universidad de Santiago de Chile \\ Alameda 3363, Santiago, Chile \\ Tel: 5627764017 \\ Fax: 5627764796 \\ E-mail: cmartine@usach.cl \\ Cecilia Gertosio \\ Departamento de Ciencia y Tecnología de los Alimentos \\ Facultad Tecnológica \\ Universidad de Santiago de Chile \\ Alameda 3363, Santiago, Chile \\ Tel: 5626810489 \\ Fax: 5626823536 \\ E-mail:cgertosi@lauca.usach.cl

\section{Angelica Labbe} \\ Departamento de Ciencia y Tecnología de los Alimentos \\ Facultad Tecnológica \\ Universidad de Santiago de Chile \\ Alameda 3363, Santiago, Chile \\ Tel: 5627764017 \\ Fax: 5627764796 \\ E-mail: lamap@usach.cl

\section{Rafael Pérez} \\ Departamento de Ciencia y Tecnología de los Alimentos \\ Facultad Tecnológica \\ Universidad de Santiago de Chile \\ Alameda 3363, Santiago, Chile \\ Tel: 5627764017 \\ Fax: 5627764796 \\ E-mail:lamap@usach.cl

\section{Maria Angélica Ganga*} \\ Departamento de Ciencia y Tecnología de los Alimentos \\ Facultad Tecnológica and Centro de Estudios en Ciencia y Tecnología de los Alimentos \\ Universidad de Santiago de Chile \\ Alameda 3363, Santiago, Chile \\ Tel: 5627764017 \\ Fax: 5627764796 \\ E-mail: aganga@usach.cl
}

Financial support: This investigation was financed by the grant Fondef D98I1037, Chile.

Keywords: $\alpha$-L-arabinofuranosidase yeast, enzymes, wine.

Abbreviations: Abf: $\alpha$-arabinofuranosidase

YPD: yeast peptone glucose

Rhodotorula glutinis is a yeast that secretes the enzyme $\alpha$-L-arabinofuranosidase (E.C. 3.2.1.55) into the culture medium and thus has an interesting biotechnological potential. To determine improved culture conditions of this organism, different factors of the culture media were evaluated such as the use of peptone as nitrogen

*Corresponding author 
source, salts composition, $\mathrm{pH}$ and growth temperature. Likewise, beet molasses and beet cosette were tested as industrial carbon sources to induce the production of the enzyme and how they influence the yeast growth. Based on these studies a culture medium is proposed for growth of this yeast in a continuous system. By assaying different dilution rates an average specific activity for the enzyme of $82.4 \mathrm{U} / \mathrm{mg}$ of protein was obtained.

The study of the aromas of fruits has revealed an important source of volatile compounds that may enrich the aromatic profile of juices and fermented drinks. The chemical composition of these potential aromas is formed by volatile compounds such as monoterpenes, derived from shikimate or $\mathrm{C} 13$ nonsoprenoids, which are linked to $\beta$-D-glucosides or diglicosides (Williams et al. 1982; Gunata et al. 1985). These compounds linked to sugars are released in two steps: initially, an $\alpha$-arabinofuranosidase (Abf), an $\alpha$ rhamnosidase or a $\beta$-apiosidase participate, followed closely by the action of a $\beta$-D-glucosidase (Gunata et al. 1988). Many of these aromatic compounds are naturally liberated during the fruit ripening (Cordonnier et al. 1989); however, the enzymatic activities of the plants are unable to liberate them completely leaving an important source of potential aromas in the juice (Gunata et al. 1985; Cordonnier et al. 1989). Therefore, some studies have been carried out to obtain endogenous enzymes, mainly from fungi and yeasts, which release these aromas. In general, these studies have been centred on identifying microorganisms with $\beta$-glucosidase activities and very few microorganisms have been considered that secrete the enzymes that participate in the first step of the reactions of the release of aromatic compounds (Gunata et al. 1990; Dupin et al. 1992; Gueguen et al. 1995; Lounteri et al. 1995; Charoenchai et al. 1997; Le Clinche et al. 1997, Spagna et al. 1998; Fernández et al. 2000; Manzanares et al. 2000; Spagna et al. 2000; Gallego et al. 2001; Strauss et al. 2001; Belancic et al. 2003). Generally, the glycosylated compounds are formed by a non-reductor $\alpha$-Larabinofuranoside (Gunata et al. 1990); therefore it would be interesting to use enzymes that hydrolyze this bond and allow the liberation of the volatile compound through the action of a $\beta$-glucosidase. This sequence of enzymatic activities would permit the enrichment of the aromatic profile of the product.

In grapes, the most abundant volatile compounds are monoterpenes, which can be free or linked to the disaccharides arabinofuranosilglucosides of geraniol, nerol and linalool (Williams et al. 1982; Gunata et al. 1988).

The $\alpha$-L-arabinofuranosidase activity (E.C. 3.2.1.55) has been mainly described in fungus (Rombouts et al. 1988; Gunata et al. 1990; Le Clinche et al. 1997; De Ioannes et al. 2000). However, due to the physicochemical characteristics of some products, such as wine, it is difficult to maintain the enzymatic activities stable during the elaboration process. Therefore, some authors have searched for enzymes from microorganisms that participate in the must fermentation process like yeasts, and these studies have been mainly focused on the $\beta$-glucosidase activity more than on the activities responsible for hydrolysis of the disaccharide bond (Gueguen et al. 1995; Manzanares et al. 1999; Charoenchai et al. 1997; Fernández et al. 2000; Strauss et al. 2001; Belancic et al. 2003).

In light of the potential use that an Abf activity would have in the enological industry, in this work we studied the culture conditions of $R$. glutinis, a yeast that has been shown to produce Abf and are naturally present in fermentative processes. Furthermore, we evaluated the specific activity of this enzyme under continuous culture.

\section{MATERIALS AND METHODS}

\section{Microorganism}

Rhodotorula glutinis strain L-1816 was isolated from Cabernet Sauvignon grapes and was maintained on YPD medium containing 2\% (w/v) glucose, 2\% (w/v) peptone and $1 \%(\mathrm{w} / \mathrm{v})$ yeast extract.

\section{Growth and culture assays}

The yeast inoculums for batch and continuous culture with $1 \times 10^{6}$ cells $/ \mathrm{mL}$ were obtained by growth in YPD. Duplicate batch cultures were carried out in 250-mL flasks with $125 \mathrm{~mL}$ of assayed medium under mechanical shaking at $150 \mathrm{rpm}$. During the culture period growth was monitored by measuring absorbance at $475 \mathrm{~nm}$ every 0.5 and $1 \mathrm{hr}$, depending on the growth phase in which the culture was found. The dry cell mass concentration was determined from the optical density reading by using the following equation: dry cell mass $=0.31 \mathrm{OD}_{475}, 0.31$ being the slope of a standard curve of dry cell mass (in $\mathrm{g} / \mathrm{L}$ ) versus $\mathrm{OD}_{475}\left(\mathrm{r}^{2}=0.9931\right)$. The specific growth rates $(\mu)$ were calculated by least-squares fitting to the linear part of

Table 1. Specific growth rates of $R$. glutinis L-1816 with different compositions of salts in the basal culture media. Means followed by different superscripted letters are significantly different $(p<0.05)$.

\begin{tabular}{|l|c|c|c|c|}
\hline & $\begin{array}{c}\text { Salts I } \\
\text { Composition }\end{array}$ & $\begin{array}{c}\text { Salts II } \\
\text { Composition }\end{array}$ & $\begin{array}{c}\text { Salts III } \\
\text { Composition }\end{array}$ & $\begin{array}{c}\text { Salts IV } \\
\text { Composition }\end{array}$ \\
\hline Specific growth rate $\left(\mathrm{h}^{-1}\right)$ & $0.198 \pm 0.05^{\mathrm{a}}$ & $0.131 \pm 0.008^{\mathrm{b}}$ & $0.100 \pm 0.004^{\mathrm{c}}$ & $0.097 \pm 0.011^{\mathrm{c}}$ \\
\hline
\end{tabular}


Table 2. Qualitative determination of Abf activity with beet molasses and beet cosette as carbon sources. Degree of Abf activity: +++, high; ++, medium; + low.

\begin{tabular}{|c|c|c|}
\hline & \multicolumn{2}{|c|}{ Abf activity } \\
\hline Concentration $(\% \mathrm{w} / \mathrm{v})$ & Beet molasses & Beet cosette \\
\hline 0.2 & +++ & ++ \\
\hline 0.5 & ++ & ++ \\
\hline 1.0 & ++ & ++ \\
\hline 2.0 & + & ++ \\
\hline
\end{tabular}

the semilog growth plot. The basal culture media used contained $0.5 \%(\mathrm{w} / \mathrm{v})$ yeast extract and a salts solution composed of $0.3 \%(\mathrm{w} / \mathrm{v})\left(\mathrm{NH}_{4}\right)_{2} \mathrm{SO}_{4}, 0.1 \%(\mathrm{w} / \mathrm{v}) \mathrm{KH}_{2} \mathrm{PO}_{4}$ and $0.05 \%(\mathrm{w} / \mathrm{v}) \mathrm{MgSO}_{4} \times 7 \mathrm{H}_{2} \mathrm{O}$. Modifications to the basal media are described below. Similarly, different $\mathrm{pH}$ and temperature conditions were evaluated.

As a way of defining an improved culture media for the growth of $R$. glutinis, several modifications to the basal media were evaluated. Growth assays of the yeast were carried out in basal media with and without peptone. Furthermore, assays were carried out with different types and concentration of salts denominated II $(0.3 \%(\mathrm{w} / \mathrm{v})$ $\left(\mathrm{NH}_{4}\right)_{2} \mathrm{SO}_{4}, 0.1 \%(\mathrm{w} / \mathrm{v}) \mathrm{KH}_{2} \mathrm{PO}_{4}, 0.05 \%$ (w/v) $\mathrm{MgSO}_{4} \mathrm{x}$ $7 \mathrm{H}_{2} \mathrm{O}$ and $\left.0.005 \%(\mathrm{w} / \mathrm{v}) \mathrm{FeSO}_{4} \times 7 \mathrm{H}_{2} \mathrm{O}\right)$, III $(0.3 \%(\mathrm{w} / \mathrm{v})$ $\left(\mathrm{NH}_{4}\right){ }_{2} \mathrm{SO}_{4}, 0.1 \%(\mathrm{w} / \mathrm{v}) \mathrm{KH}_{2} \mathrm{PO}_{4}, 0.05 \%$ (w/v) $\mathrm{MgSO}_{4} \mathrm{x}$ $7 \mathrm{H}_{2} \mathrm{O}$ and $\left.0.001 \%(\mathrm{w} / \mathrm{v}) \mathrm{MnCl}_{2} \times 4 \mathrm{H}_{2} \mathrm{O}\right)$ and $\mathrm{IV}(0.3 \%$ (w/v) $\left(\mathrm{NH}_{4}\right){ }_{2} \mathrm{SO}_{4}, 0.1 \%(\mathrm{w} / \mathrm{v}) \quad \mathrm{KH}_{2} \mathrm{PO}_{4}, 0.05 \%(\mathrm{w} / \mathrm{v})$ $\mathrm{MgSO}_{4} \times 7 \mathrm{H}_{2} \mathrm{O}, 0.005 \%(\mathrm{w} / \mathrm{v}) \mathrm{FeSO}_{4} \times 7 \mathrm{H}_{2} \mathrm{O}$ and $0.001 \%$ (w/v) $\mathrm{MnCl}_{2} \times 4 \mathrm{H}_{2} \mathrm{O}$ ). The salts composition of the basal culture media was denominated as salt composition I. Finally, as a means of determining the influence of the carbon source on the yeast growth, $2 \%(\mathrm{w} / \mathrm{v})$ beet cosette and $2 \%(\mathrm{w} / \mathrm{v})$ beet molasses were also evaluated. For this, the beet cosette was weighed, grinded and mixed with 100 $\mathrm{mL}$ distilled water. This mix was vigorously agitated and kept at $80^{\circ} \mathrm{C}$ for 20 to $30 \mathrm{~min}$. Subsequently, it was filtered using a Watman $\mathrm{N}^{\circ} 1$ filter paper for use in the preparation of the culture media.

The effect of the culture temperature on the growth of the yeast was also studied. The temperatures assayed were 20, 25,28 and $37^{\circ} \mathrm{C}$. Furthermore, the effect of the culture media $\mathrm{pH}$ on the growth of $R$. glutinis was determined. The cultures were initially adjusted to $\mathrm{pH} 4.0$ or 5.2 . The $\mathrm{pH}$ was adjusted using $0.5 \mathrm{M}$ citric acid.

\section{Enzymatic assays}

The $\alpha$-L-arabinofuranosidase activity was qualitatively determined according to Ganga and Martínez (2004). In brief, Petri dishes with culture media containing $0.17 \%$ $(\mathrm{w} / \mathrm{v})$ yeast nitrogen base (YNB, Difco); $0.5 \%(\mathrm{w} / \mathrm{v})$ ammonium sulphate, $0.004 \%$ (w/v) 4-methylumbelliferyl$\alpha$-L-arabinofuranoside (Sigma) and 2\% (w/v) agar-agar were used. The carbon sources assayed were beet cosette (Industria Azucarera Nacional S.A (Iansa)-Chile) and beet molasses (Iansa-Chile) at $0.2,0.5,1$ and $2 \%(\mathrm{w} / \mathrm{v})$ concentrations as indicated. The glycosidase activity was observed by the presence of UV fluorescence around the colony. To quantify the Abf activity, the culture media was centrifuged at $8000 \mathrm{~g}$ for $15 \mathrm{~min}$ at $10^{\circ} \mathrm{C}$. The supernatant was concentrated 20 times using a Minitan ultrafiltration system (Millipore Corp. Bedford, MA) with a 10,000 molecular weight cutoff polysulfone filter. The culture media without inoculum served as a control. The Abf quantification was done using $4 \mathrm{mM} p$-nitrophenyl- $\alpha$-Larabinofuranoside $(p \mathrm{NP} \alpha \mathrm{AF}) \quad$ (Sigma) as substrate according to the methodology used by Le Clinche et al. (1997). Assays were performed by incubating a reaction mixture containing $250 \mu \mathrm{L}$ of $1 \mathrm{mM}$ of substrate in $50 \mathrm{mM}$ succinate buffer, $\mathrm{pH} 5.5$ and $250 \mu \mathrm{L}$ of culture media at $40^{\circ} \mathrm{C}$ for $20 \mathrm{~min}$. The reaction was stopped by addition of 1 $\mathrm{mL}$ of $2 \mathrm{M} \mathrm{Na}_{2} \mathrm{CO}_{3}$, and the liberation of $p$-nitrophenol was measured spectrophotometrically at $405 \mathrm{~nm}$. One unit of enzyme activity was defined as the amount of enzyme necessary for the formation of $1 \mu \mathrm{mol}$ of $p$-nitrophenol per minute under the conditions of the assay. The protein quantification was carried out according to the equation $\mathrm{A}_{205} /\left(27+120\left(\mathrm{~A}_{280} / \mathrm{A}_{205}\right)\right)$ with readings at both $205 \mathrm{~nm}$ and $280 \mathrm{~nm}$ wavelengths (Scopes, 1974).

\section{Production of $\boldsymbol{R}$. glutinis in a continuous system}

The growth of $R$. glutinis was carried out in a laboratory constructed fermentor under continuous operation. The fermentor was constructed with a $1 \mathrm{~L}$ glass vessel (with an internal diameter of $9.4 \mathrm{~cm}$ and $15.34 \mathrm{~cm}$ in height) submerged $14 \mathrm{~cm}$ in a controlled water bath. The system was agitated at $200 \mathrm{rpm}$ with a magnetic stir plate (Heidolph, Germany), and fed with sterile culture media by a flow controlled peristaltic pump (Masterflex, USA). Furthermore, sterile air was injected by the use of a compressor and the flow regulated with a flowmeter (Gilmont Instruments, USA). The system was equipped with a $\mathrm{pH}$ probe and an acid/base flow controlled system (Cole Parmer Instruments Co, USA). Antifoam was added manually through a sterile syringe connected to the fermentor. The culture media was defined in the present study. The fermentation conditions were $1 \mathrm{~L} / \mathrm{min}$ of air flow, $\mathrm{pH} 5.2$ and $28^{\circ} \mathrm{C}$.

\section{Statistical analyses}

Statistical analyses were performed with Statgraphics Plus 4.0 software. Differences between treatment means were compared using the least significant differences (LSD) test with confidence level of $95 \%$.

\section{RESULTS AND DISCUSSION}


As a way of estimating how the constituents of the culture media influence the growth of $R$. glutinis and the production of Abf, different culture assays were carried out varying the composition of our base medium as indicated above.

\section{Effect of peptone on yeast growth}

The yeast $R$. glutinis L-1816 was tested for its capacity to grow, with or without $0.5 \%(\mathrm{w} / \mathrm{v})$ peptone at $25^{\circ} \mathrm{C}$, in the basal culture media supplemented with $2 \%(\mathrm{w} / \mathrm{v})$ glucose as a carbon source. At $72 \mathrm{hrs}$ of yeast growth, a basal value of $199 \pm 0.007 \mathrm{~h}^{-1}$ was obtained, whilst for basal medium plus peptone the value was $0.191 \pm 0.022 \mathrm{~h}^{-1}$, both being statistically similar.Peptone is a broadly used component of yeast culture media because it is a rich source of nitrogen. However, our results showed that the specific growth rate is not dependent on the presence of peptone in the culture media. These suggest that the basal media used in our study contains an adequate amount of nitrogen salts that are easy assimilated by the yeast and consequently peptone would not be necessary for yeast growth, at least during the time that the assays were carried out.

\section{Effects of the media salts composition on yeast growth}

Cho et al. (2001) have shown that the use of different nitrogen sources in culture media affects yeast growth. Therefore, a study was carried out to determine the most adequate salts composition in the culture media for optimum growth of the yeast strain used in our investigation. In these experiments, we evaluated the specific growth rates of $R$. glutinis L-1816 using the basal media without peptone and varying the type and concentration of salts as is described in Material and Methods. As before, growth was followed for $72 \mathrm{hrs}$ at $25^{\circ} \mathrm{C}$ with $2 \%(\mathrm{w} / \mathrm{v})$ glucose as a carbon source (Table 1).

The salts composition I $\left(0.3 \%\right.$ (w/v) of $\left(\mathrm{NH}_{4}\right)_{2} \mathrm{SO}_{4} ; 0.1 \%$ $(\mathrm{w} / \mathrm{v})$ of $\mathrm{KH}_{2} \mathrm{PO}_{4}$ and $0.05 \%(\mathrm{w} / \mathrm{v})$ of $\mathrm{MgSO}_{4} \times 7 \mathrm{H}_{2} \mathrm{O}$ ) is an adaptation of that described for Rhodotorula flava by Uesaka et al. (1978) and our results show that it also is enough to support the growth of $R$. glutinis L-1816, being superior to the other salts compositions evaluated. The addition of Fe or Mn in the salts composition II, III or IV seems to not have important effects on yeast growth. The growth rate values showed by $R$. glutinis L-1816 in the presence of these minerals are lower than those obtained using salt composition I, which does not possess any of these metals. Likewise, it can be observed that the increase of $\mathrm{KH}_{2} \mathrm{PO}_{4}$ and $\mathrm{MgSO}_{4} \times 7 \mathrm{H}_{2} \mathrm{O}$ concentration could have a negative effect on yeast growth.

\section{Study of industrial carbon sources for $R$. glutinis L-1816 growth and Abf production}

The industrial carbon sources such as beet molasses and beet cosette have been used in the production of this yeast
(Roche et al. 1994; Luonteri et al. 1995; De Ioannes et al. 2000). Likewise, beet cosette has been studied as a cheap substrate source in Chile for some enzyme-producing microorganisms, especially fungi (Illanes et al. 1992; Chamy et al. 1994). Considering this information, we studied the effect of these industrial carbon sources on the growth of the yeast and the production of Abf. For this, the growth and Abf activity of $R$. glutinis L-1816 were evaluated in basal media at $25^{\circ} \mathrm{C}$ and an initial $\mathrm{pH}$ of the culture medium of 5.2 (see below). The media was supplemented with $2 \%(\mathrm{w} / \mathrm{v})$ of the carbon sources as is indicated. The specific growth rates were determined from $72 \mathrm{hrs}$ cultures showing that beet cosette support the lowest specific growth rate $\left(\mu=0.151 \pm 0.012 \mathrm{~h}^{-1}\right)$ in comparison to glucose $\left(\mu=0.205 \pm 0.010 \mathrm{~h}^{-1}\right)$ and beet molasses $(\mu=$ $\left.0.219 \pm 0.007 \mathrm{~h}^{-1}\right)$, where these latter carbon sources did not show significant differences in this growth parameter $(p<$ 0.05 ). Rubio et al. (2002) described that $R$. glutinis has a high invertase activity that would allow the use of media with a high sugar content such as beet molasses. On the other hand, beet cosette presents cellulose and hemicellulose content with only $3.7 \mathrm{~g} / \mathrm{L}$ of reducing sugars (Illanes and Schaffeld, 1983). This fact could explain the low growth rate observed when the yeast is cultivated with beet cosette, since there would be little availability of easily assimilated carbon substrates when compared with the other two carbon sources assayed.

Because the production of Abf in microorganisms is dependent on the substrate present in the culture media (De Ioannes et al. 2000) and considering the eventual applicability of beet molasses or beet cosette as industrial carbon sources for yeast growth, we study the effect of these two substrates on the production of Abf in qualitative assays. For this, R. glutinis L-1816 was grown in petri dishes with different concentrations of beet molasses or beet cosette (Table 2). Our results show that an increase in beet molasses concentration has a negative effect on the Abf activity. This observation could be a consequence of an increase in the sucrose content present in beet molasses whichcan have an inhibitory effect on the production of Abf. For practical considerations, the greatest enzyme secretion was obtained at a concentration of $0.2 \%(\mathrm{w} / \mathrm{v})$ of beet molasses. Also, beet molasses has approximately $62 \%$ $(\mathrm{w} / \mathrm{v})$ of carbohydrates and other residues that could induce the production of Abf by the yeast.

Table 3. Effects of initial $\mathrm{pH}$ of the culture media on the growth of $\boldsymbol{R}$. glutinis L-1816. Means followed by different superscripted letters are significantly different $(p<0.05)$

\begin{tabular}{|c|c|}
\hline $\mathbf{p H}$ & Specific growth rate $\left.\mathbf{( h}^{-1}\right)$ \\
\hline 4.0 & $0.156 \pm 0.001^{\mathrm{a}}$ \\
\hline 5.2 & $0.197 \pm 0.130^{\mathrm{b}}$ \\
\hline
\end{tabular}


On the other hand, the effect shown by the beet cosette on the production of Abf by R. glutinis L-1816 is independent of its concentration in the culture media. Illanes and Schaffeld (1983) by a hydrolysis experiment of this substrate indicated that its chemical composition includes $58.5 \%(\mathrm{w} / \mathrm{v})$ of crude fiber. In our case, a hydrolysis was not carried out prior to its incorporation into the culture media, however, part of these components may have passed into solution and it is therefore possible that some induce the production of Abf. De Ioannes et al. (2000) showed that for the case of Penicillium purpurognum, beet cosette is a good inducer for the production of this enzyme.

\section{Effects of temperature and initial $\mathrm{pH}$ of the culture media on yeast growth}

The growth temperature conditions described for $R$. glutinis have been $22^{\circ} \mathrm{C}$ (Cho et al. 2001) and $30^{\circ} \mathrm{C}$ (Buzzini and Martin, 2000; Rubio et al. 2002). As a way of defining an adequate temperature for the growth of the yeast under our conditions, assays were carried out using culture temperatures of: $20,25,28$ and $37^{\circ} \mathrm{C}$. In these assays, we estimated the specific growth rates of $R$. glutinis L-1816 at the temperatures indicated using the basal media without peptone. As before, yeast growth was monitored for $72 \mathrm{hrs}$ with $2 \%(\mathrm{w} / \mathrm{v})$ glucose as a carbon source. Our results suggest that $28^{\circ} \mathrm{C}$ is the optimum growth temperature, with a specific growth rate value of $0.198 \pm 0.006 \mathrm{~h}^{-1}$, although previous reports have obtained yeast growth at $37^{\circ} \mathrm{C}$ (Kurtzman and Feel, 1999).

On the other hand, we have carried out assays in Petri dishes of several native isolates to obtain yeasts with $\mathrm{Abf}$ activity (Ganga and Martínez, 2004). As a continuation of these studies, we found that $R$. glutinis L-1816 presents this activity at an acid $\mathrm{pH}$ (data not shown). As a way of evaluating the effects of the acid culture media on the growth of this yeast strain, assays were carried out in culture media with an initial $\mathrm{pH}$ of 4.0, 5.2 and 7.0. Cho et al. (2001) showed that this yeast showed an important biomass production at an initial $\mathrm{pH}$ of between 4.0 and 7.0. Our results are shown in Table 3 and indicate that at an initial $\mathrm{pH}$ of 5.2, in unbuffered media, the yeast growth rate is greater. Under our culture conditions and $\mathrm{pH} 7.0$, only a residual growth was observed.

The study of $\mathrm{pH}$ evolution in unbuffered $R$. glutinis L-1816
$72 \mathrm{hrs}$ cultures showed an increase of this parameter reaching a value of 7.0, when basal media without peptone at $28^{\circ} \mathrm{C}$ and beet molasses as carbon source was used. Therefore, we analyzed the effects on the yeast growth of maintaining the $\mathrm{pH}$ stable during the whole growth period using phosphate citrate $\mathrm{pH} 5.2$ as buffer. Our results showed that there are no statistical differences in the specific growth rate of the yeast using media at a constant $\mathrm{pH}$ of 5.2 or media without $\mathrm{pH}$ control but with an initial $\mathrm{pH}$ of 5.2. Furthermore, the biomass concentration values at the end of the growth period showed differences of less than $6 \%$. Since growth of this yeast is affected by neutral $\mathrm{pHs}$ and these values are observed in our studies in batch cultures, it is therefore important to control this parameter in continuous cultures.

Considering the assays above, we proposed that the best growth conditions for Abf production by $R$. glutinis L-1618 are $0.2 \%(\mathrm{w} / \mathrm{v})$ beet molasses, $0.3 \%(\mathrm{w} / \mathrm{v})\left(\mathrm{NH}_{4}\right)_{2} \mathrm{SO}_{4}, 0.1 \%$ (w/v) $\mathrm{KH}_{2} \mathrm{PO}_{4}, 0.05 \%(\mathrm{w} / \mathrm{v}) \mathrm{MgSO}_{4} \times{ }_{7} \mathrm{H}, 0.5 \%(\mathrm{w} / \mathrm{v})$ yeast extract, $\mathrm{pH} 5.2$ and $28^{\circ} \mathrm{C}$.

\section{Production of $\alpha$-arabinofuranosidase in a continuous system}

Using the culture conditions described in the previous paragraphs, the growth of $R$. glutinis L-1816 was carried out in a continuous culture system for $80 \mathrm{hrs}$ to produce Abf. Two dilution rates were assayed as is shown in Table 4. Under these conditions it was possible to obtain a positive correlation between dilution rate and Abf activity, where the latter increased almost five times. Furthermore, an increase in the production of total proteins is also observed, which allowed the specific activity of the enzyme under study be maintained constant.

Uesaka et al. (1978) by growing $R$. flava in a medium with purified beet arabinan as carbon source obtained an $\alpha$ arabinofuranosidase activity of $3.6 \mathrm{mU} / \mathrm{mL}$, a lower value than that obtained in our study at the different flow velocities assayed. On the other hand, the specific activity described by these authors was $0.26 \mathrm{U} / \mathrm{mg}$. In our case, the specific activity obtained for the $R$. glutinis strain L-1816, did not show significant differences between the flows velocities assayed, obtaining an average value of 82.4 $\mathrm{U} / \mathrm{mg}$, approximately 23 times greater than that described by Uesaka et al. (1978). This is mainly because of the low

Table 4. $\alpha$-L-arabinofuranosidase production in a continuous culture reactor at different flow velocities. Means within the same column followed by different superscripted letters are significantly different $(p<0.05)$.

\begin{tabular}{|c|c|c|c|c|}
\hline $\mathbf{D}\left(\mathbf{h}^{-1}\right)$ & $\begin{array}{c}\text { Enzyme activity } \\
(\mathbf{m U} / \mathbf{m L})\end{array}$ & $\begin{array}{c}\text { Total proteins } \\
(\mathbf{\mu g} / \mathbf{m L})\end{array}$ & $\begin{array}{c}\text { Specific activity } \\
(\mathbf{m U} / \mathbf{\mu g})\end{array}$ & $\begin{array}{c}\text { Enzyme activity } \\
(\mathbf{m U / g} \text { dry weight })\end{array}$ \\
\hline 0.064 & $29.238 \pm 2.617^{\mathrm{a}}$ & $0.349 \pm 0.089^{\mathrm{a}}$ & $83.775 \pm 28.885^{\mathrm{a}}$ & $16.565 \pm 2.806^{\mathrm{a}}$ \\
\hline 0.178 & $145.571 \pm 13.957^{\mathrm{b}}$ & $1.798 \pm 0.810^{\mathrm{b}}$ & $80.951 \pm 44.231^{\mathrm{a}}$ & $105.640 \pm 3.4046^{\mathrm{b}}$ \\
\hline
\end{tabular}


amount of proteins secreted by the yeast, which could correspond to the enzyme under study and therefore our growth conditions for this yeast permit a greater increase in the Abf production.

\section{REFERENCES}

BUZZINI, Pietro and MARTIN, Alessandro. Production of carotenoids by strains of Rhodotorula glutinis cultured in raw materials of agro-industrial origin. Bioresource Technology, January 2000, vol. 71, no. 1, p. 41-44.

BELANCIC, Andrea; GUNATA, Ziya; VALLIER, MarieJose and AGOSIN, Eduardo. $\beta$-glucosidase from the grape native yeast Debaryomyces vanrijiae: purification, characterization, and its effect on monoterpene content of a muscat grape juice. Journal of Agricultural and Food Chemistry, February 2003, vol. 51, no. 5, p.1453-1459.

CHAMY, R.; ILLANES, A.; AROCA, G. and NUÑEZ, L. Acid hydrolysis of sugar beet pulp as pretreatment for fermentation. Bioresource Technology, 1994, vol. 50, no. 2, p. $149-152$.

CHAROENCHAI, C.; FLEET, G.H.; HENSCHKE, P.A. and TODD, B.E.N. Screening of non- Saccharomyces wine yeasts for the presence of extracellular hydrolytic enzymes. Australian Journal of Grape and Wine Research, 1997, vol. 3, no. 1, p. 2-8.

CHO, Dae Haeng; CHAE, Hee Jeong and KIM, Eui Yong. Synthesis and characterization of a novel extracellular polysaccharide by Rhodotorula glutinis. Applied Biochemistry and Biotechnology, December 2001, vol. 95, no. 3, p. 183-194.

CORDONNIER, R.; GUNATA, Z.; BAUMES, R. and BAYONOVE, C. Recherche d'un matériel enzymatic adapté a l'hidrolyse des précurseurs d'arôme de nature glycosidique du raisin. Connaissanse de la Vigne et du Vin, 1989, vol. 23 , no. 1, p. 7-23.

DE IOANNES, Pablo; PEIRANO, Alessandra; STEINER, Jeannette and EYZAGUIRRE, Jaime. An $\alpha$-Larabinofuranosidase from Penicillium purpurogenum: production, purification and properties. Journal of Biotechnology, January 2000, vol. 76, no. 2-3, p. 253-258.

DUPIN, Isabelle; GUNATA, Ziya; SAPIS, Jean Claude; M'BAIRAROUA, Oubadjim; TAPIERO, Claude and BAYONOVE, Claude. Production of $\beta$-apiosidase by Aspergillus niger: partial purification, properties, and effect on terpenyl apiosylglucosides from grape. Journal of Agricultural and Food Chemistry, October 1992, vol. 40, no. 10 , p. $1886-1891$.

FERNÁNDEZ, M.; UBEDA, J.F. and BRIONES, A.I. Typing of non-Saccharomyces yeast with enzymatic activities of interest in wine-making. International Journal of Food Microbiology, July 2000, vol. 59, no. 1-2, p. 29-36.
GANGA, M.A. and MARTÍNEZ, C. Effect of wine yeast monoculture practice on the biodiversity of non Saccharomyces yeasts. Journal of Applied Microbiology, January 2004, vol. 96, no. 1, p. 76-83.

GALLEGO, M.; PIÑAGA, F.; RAMON, D. and VALLES, S. Purification and characterization of an $\alpha$-L-rhamnosidase from Aspergillus terreus of interest in winemaking. Journal of Food Science, March 2001, vol. 66, no. 2, p. 204-209.

GUEGUEN, Y.; CHEMARDIN, P.; ARNAUD, A. and GALZY, P. Comparative study of extracellular and intracellular $\beta$-glucosidase of a new strain of Zygosaccharomyces bailii isolated from fermenting agave juice. Journal of Applied Bacteriology, 1995, vol. 78, no. 3, p. $270-280$.

GUNATA, Ziya; BAYONOVE, Claude; BAUMES, Raymond and CORDONNIER, Robert. The aroma of grapes. Localisation and evolution of free and bound fractions of some grape aroma components cv. Muscat during first development and maturation. Journal of the Science of Food and Agriculture, 1985, vol. 36, no. 9, p. 857-862.

GUNATA, Ziya; BITTEUR, Sylvaine; BRILLOUET, JeanMarc; BAYONOVE, Claude and CORDONNIER, Robert. Sequential enzymic hydrolysis of potentially aromatic glycosides from grape. Carbohydrates Research, December 1988, vol. 184, p. 139-149.

GUNATA, Ziya; BRILLOUET, Jean Marc; VOIRIN, Stephane; BAUMES, Raymond and CORDONNIER, Robert. Purification and some properties of an $\alpha$-Larabinofuranosidase from Aspergillus niger: action on grape monoterpenyl arabinofuranosylglucosides. Journal of Agricultural and Food Chemistry, March 1990, vol. 38, no 3, p. 772-776.

ILLANES, A. and SCHAFFELD, G. Protein enrichment of treated and untreated leached beet cosette. Biotechnology Letters, May 1983, vol. 5, no. 5, p. 305-310.

ILLANES, A.; AROCA, G.; CABELLO, L. and ACEVEDO, F. Solid substrate fermentation of leached beet pulp with Trichoderma aureoviride. World Journal of Microbiology and Biotechnology, September 1992, vol. 8, no. 5, p. 488-493.

KURTZMAN, C. and FEEL, J. The yeasts: a taxonomic study. $4^{\text {th }}$ edition. Elsevier Science B. V. Amsterdam, The Netherlands, 1999. 1055 p. ISNB: 0-444-81312-8.

LE CLINCHE, Florence; PIÑAGA, Francisco; RAMON, Daniel and VALLES, Salvador. $\alpha$-L-arabinofuranosidases from Aspergillus terreus with potential application in enology: Induction, purification and characterization. Journal of Agricultural and Food Chemistry, July 1997, vol. 45, no. 7, p. 2379-2383. 
LUONTERI, E.; SIIKA-AHO, M.; TENKANEN, M. and VIIKARI, L. Purification and characterization of three $\alpha$ arabinosidases from Aspergillus terreus. Journal of Biotechnology, January 1995, vol. 38, no. 3, p. 279-291.

MANZANARES, Paloma; RAMON, Daniel and QUEROL, Amparo. Screening of non-Saccharomyces wine yeasts for the production of $\beta$-D-xylosidase activity. International Journal of Food Microbiology, February 1999, vol. 46, no. 2, p. 105-112.

MANZANARES, P.; OREJAS, M.; IBAÑEZ, E.; VALLES, S. and RAMON, D. Purification and characterization of an $\alpha$-L-rhamnosidase from Aspergillus nidulans. Letters in Applied Microbiology, September 2000, vol. 31, no. 3, p. 198-202.

ROCHE, N.; DESGRANGES, C. and DURAN, A. Study on the solid-stated production of a thermostable $\alpha$-Larabinofuranosidase of Thermoascus aurantiacus on sugar beet pulp. Journal of Biotechnology, November 1994, vol. 38 , no. 1, p. $43-50$.

ROMBOUTS, F.; VORAGEN, A.; SEARLE-VAN LEEUWEN, M.; GERAEDS, C.; SCHOLS, H. and PILNIK, E. The arabinases of Aspergillus nigerpurification and characterization of two $\alpha$-Larabinofuranosidases and an endo 1,5- $\alpha$-arabinase. Carbohydrate Polymers, 1988, vol. 8, no. 1, p. 25-47.

RUBIO, María C.; RUNCO, Rosa and NAVARRO, Antonio R. Invertase from a strain of Rhodotorula glutinis. Phytochemistry, November 2002, vol. 61, no. 6, p. 605-609.

SCOPES, R.K. Measurement of protein by spectrophotometry at $205 \mathrm{~nm}$. Analytical Biochemistry, May 1974, vol. 59, no. 1, p. 277-282.

SPAGNA, Giovanni; ROMAGNOLI, Denis; MARTINO, Angela; BIANCHI, Giovanni and PIFFERI, Pier Giorgio. A simple method for purifying glycosidases: $\alpha$-Larabinofuranosidase and $\beta$-D-glucopyranosidase from Aspergillus niger to increase the aroma of wine. Part I. Enzyme and Microbial Technology, April 1998, vol. 22, no. 5, p. 298-304.

SPAGNA, Giovanni; BARBAGALLO, Riccardo N.; MARTINO, Angela and PIFFIERI, Pier Giorgio. A simple method for purifying glycosidases: $\alpha$-Lrhamnopyranosidase from Aspergillus niger to increase the aroma of Moscato wine. Enzyme and Microbial Technology, October 2000, vol. 27, no. 7, p. 522-530.

STRAUSS, M.L.A.; JOLLY, N.P.; LAMBRECHTS, M.G. and VAN RENSBURG, P. Screening for the production of extracellular hydrolytic enzymes by non-Saccharomyces wine yeasts. Journal of Applied Microbiology, July 2001, vol. 91, no. 1, p. 182-190.
UESAKA, E.; SATO, M.; RAIJU, M. and KAJI, A. $\alpha$-LArabinofuranosidase from Rhodotorula flava. The Journal of Bacteriology, March 1978, vol. 133, no. 3, p. 1073-1077.

WILLIAMS, Patrick J.; STRAUSS, Christopher R.; WILSON, Bevan and MASSY-WESTROPP, Ralph A. Novel monoterpene disaccharide glycosides of Vitis vinifera grapes and wines. Phytochemistry, 1982, vol. 21, no. 8, p. 2013-2020. 